\title{
Haemodynamic and neurohumoral response to exercise in patients with congestive heart failure treated with captopril
}

\author{
MARK A CREAGER, DAVID P FAXON, DONALD A WEINER, THOMAS J RYAN \\ From the Evans Memorial Department of Clinical Research and the Department of Medicine, Boston University \\ Medical Center, Boston, Massachusetts, USA
}

SUMMARY The contribution of the renin-angiotensin system to the cardiovascular response to exercise was studied in 12 patients with congestive heart failure. The haemodynamic effects of captopril were measured at rest and during supine bicycle exercise. After captopril administration, resting systemic vascular resistance fell by $26.6 \%$ and mean blood pressure by $16.7 \%$ and cardiac index increased by $19.7 \%$. During exercise, captopril decreased systemic vascular resistance by $25.6 \%$ and mean blood pressure by $8 \cdot 2 \%$ and increased cardiac index by $24.4 \%$. Pulmonary wedge pressure fell by $25 \%$ at rest but was not altered by captopril during exercise. Pretreatment plasma renin activity increased from $13.4(16.0) \mathrm{ng} / \mathrm{ml} / \mathrm{hr}(10.3(12.3) \mathrm{mmol} / 1 / \mathrm{hr})$ at rest to $20.0(27.8) \mathrm{ng} / \mathrm{ml} / \mathrm{hr}(15.4(21.4)$ $\mathrm{mmol} / \mathrm{l} / \mathrm{hr}$ ) during exercise. Pretreatment plasma noradrenaline concentration increased from $659(433) \mathrm{pg} / \mathrm{ml}(39(25 \cdot 6) \mathrm{nmol} / \mathrm{l})$ at rest to $2622(1486) \mathrm{pg} / \mathrm{ml}$ during exercise $(155(88) \mathrm{nmol} / \mathrm{l})$. Captopril favourably alters systemic vascular resistance and cardiac index during exercise in patients with congestive heart failure. This may reflect inhibition of the increased activity of the reninangiotensin system during exercise in these patients and a subsequent reduction in systemic vasoconstriction.

The renin-angiotensin system contributes to systemic vasoconstriction in patients with congestive heart failure. After the administration of saralasin (an angiotensin II antagonist) and of teprotide, captopril, and enalapril (angiotensin-converting enzyme inhibitors) resting cardiac function improves as a consequence of systemic vasodilatation..$^{1-10} \mathrm{~A}$ beneficial haemodynamic response during exercise also occurs after captopril administration. This includes an increase in cardiac output and stroke volume and a fall in systemic vascular resistance. 1112 The clinical efficacy of captopril has been shown in placebo controlled trials. ${ }^{12} 13$

In resting patients the vasodilatation that accompanies converting enzyme inhibition correlates with the pretreatment resting plasma renin activity. ${ }^{278}$

Requests for reprints to Dr Mark A Creager, Division of Vascular Medicine and Atherosclerosis, Brigham and Women's Hospital, 75 Frank's Street, Boston, MA 02115, USA.

Accepted for publication 22 November 1984
While plasma renin activity also increases during exercise in normal subjects, it is not established that plasma renin activity increases in patients with heart failure during exercise. ${ }^{14} 15$ Activation of the reninangiotensin system during exercise would further contribute to vasoconstriction and as a result limit the increase in cardiac output. Captopril may, therefore, inhibit angiotensin mediated vasoconstriction during exercise and thus improve cardiac function.

Some investigators have reported a fall in plasma noradrenaline concentration after converting enzyme inhibition, though this has not been confirmed by others. ${ }^{36}$ During exercise, plasma noradrenaline increases in normal subjects and in patients with congestive heart failure. ${ }^{14-17} \mathrm{~A}$ decrease in sympathetic nervous system activity may contribute to captopril mediated vasodilatation.

This study was therefore designed to assess the haemodynamic and neurohumoral response to captopril during exercise in patients with congestive heart failure. Plasma renin activity and noradrenaline concentrations were assessed at rest and during exercise 
to determine whether haemodynamic changes seen during exercise after converting enzyme inhibition can be explained by inhibition of the reninangiotensin or sympathetic nervous systems.

\section{Patients and methods}

\section{STUDY POPULATION}

Twelve patients with symptoms and signs of severe congestive heart failure participated in the study. The group included 11 men and one woman (mean age 59(11) (range 37-74) years). The cause of congestive heart failure was coronary artery disease in six patients as documented by previous myocardial infarction or coronary angiography or both and hypertension in two. Four patients had a primary cardiomyopathy of unknown aetiology. Patients having sustained a myocardial infarction within three months or those with primary valvar pathology were excluded. The mean duration of heart failure was $5 \cdot 2(3.5)$ years (range one month to seven years). Eight of the patients were categorised as being in New York Heart Association class III and four as being in class IV. All had been receiving digitalis and diuretic drugs. The mean radionuclide ejection fraction was $23.7(11.6) \%$. The protocol of the study had the approval of the Institutional Review Board for Human Research, and each patient gave informed consent.

Patients were admitted to hospital and maintained on a diet containing $86 \mathrm{mmol}$ sodium daily for at least three days before the study. All vasodilators were withdrawn at least 48 hours before the investigation. Digitalis, diuretics, and all medications other than clinically necessary antiarrhythmic agents were withheld on the day of the haemodynamic study.

\section{CENTRAL HAEMODYNAMIC ASSESSMENT}

On the evening before the study, patients underwent right heart catheterisation with a Swan-Ganz catheter (Edwards Laboratories) and radial artery cannulation. Pressures were measured using a Hewlett-Packard model 1280 strain gauge transducer and recorded on a direct-writing Hewlett-Packard multigraph. Mean pressures were obtained by electronic integration. Zero reference was chosen at a level $5 \mathrm{~cm}$ vertically beneath the sternal angle. Heart rate was determined from the simultaneous electrocardiographic signal. Cardiac output was determined by the Fick method as detailed below. Thus measurements were obtained for systolic, diastolic, and mean blood pressure, mean pulmonary artery pressure, pulmonary capillary wedge pressure, and right atrial pressure. Hemodynamic indices and systemic resistance were calculated from pressure and output values according to standard formulas. ${ }^{18}$
RESPIRATORY GAS ANALYSIS AND

\section{DETERMINATION OF CARDIAC OUTPUT}

A Beckman metabolic cart comprising a volume transducer, a Beckman OM-11 oxygen analyser, and a Beckman UB-2 carbon dioxide analyser was used to determine minute volume oxygen consumption $\left(\hat{\mathrm{V}} \mathrm{O}_{2}\right)$, and minute volume carbon dioxide production $\left(\dot{\mathrm{V}}_{2}\right)$. Oxygen and carbon dioxide concentrations in expired air were delivered via a mouthpiece with a low resistance three way valve to a mixing chamber, volume transducer, and gas analyser. The gas analyser was calibrated with $4 \%$ carbon dioxide and $16 \%$ oxygen calibration gas. A model 1810 Monroe programmable calculator was used to calculate $\mathrm{VO}_{2}$ and $\mathrm{VCO}_{2}$. Blood was collected for arterial and mixed venous oxygen content. Blood for oxygen content was analysed on a Lex- $\mathrm{O}_{2}$-Con oxygen analyser (Lexington Instruments). Cardiac output was calculated as the ratio of the $\mathrm{VO}_{2}$ to the arteriovenous oxygen content difference.

\section{PLASMA RENIN ACTIVITY AND PLASMA NORADRENALINE CONCENTRATION MEASUREMENTS}

Samples of mixed venous blood for measurement of plasma renin activity and noradrenaline concentration were collected while the patients were resting supine and at peak exercise, before and after captopril administration. The collection of blood coincided with the haemodynamic measurements. Blood specimens for plasma renin activity and noradrenaline concentration were immediately placed on ice and centrifuged at $4^{\circ} \mathrm{C}$. Plasma renin activity was determined by a radioimmunoassay for angiotensin I generation and plasma noradrenaline concentration by a radioenzymatic assay. ${ }^{1920}$

\section{STUDY PROTOCOL}

Patients were studied after fasting overnight without premedication. Haemodynamic measurements were made while patients were lying supine. Systemic haemodynamic data were collected until three successive determinations 10 minutes apart showed homeostasis. Simultaneous respiratory gas analysis also assured a stable resting state. Patients then began exercise on a Quinton supine bicycle ergometer at a workload of $33 \mathrm{~W}$ (200 kpm), pedalling at 40 to 50 $\mathrm{rev} / \mathrm{min}$. The duration of this stage was three minutes. The workload was increased by $8 \mathrm{~W}(50 \mathrm{kpm})$ every three minutes. Haemodynamic measurements, collection of arterial and mixed venous blood for oxygen content, and respiratory gas analysis were performed during the last minute of each stage. Exercise was terminated when the patient was unable to continue because of dyspnoea or fatigue. Haemodynamic measurements and respiratory gas analysis were 
Table Effect of captopril on systemic haemodynamics and oxygen consumption at rest and during exercise. Values are mean (SD)

\begin{tabular}{|c|c|c|c|c|c|c|}
\hline & \multicolumn{3}{|l|}{ Rest } & \multicolumn{3}{|l|}{ Exercise } \\
\hline & Control & Captopril & $p$ value * & Control & Captopril & $p$ value * \\
\hline $\begin{array}{l}\mathrm{V}_{2}(\mathrm{ml} / \mathrm{min}) \\
\text { Systemic vascular resistance }\left(\text { dyn } \mathrm{s} \mathrm{cm}^{-\varsigma}\right) \\
\text { Blood pressure }(\mathrm{mm} \mathrm{Hg}) \\
\text { Cardiac index }\left(\mathrm{l} / \mathrm{min} \mathrm{per} \mathrm{m} \mathrm{m}^{2}\right) \\
\text { Stroke volume index }\left(\mathrm{ml} / \mathrm{m}^{2}\right) \\
\text { Heart rate (beats/min) } \\
\text { Pulmonary capillary wedge pressure }\end{array}$ & $\begin{array}{l}239(45) \\
2138(802) \\
99(20) \\
2 \cdot 1(0 \cdot 8) \\
26(11) \\
88(18)\end{array}$ & $\begin{array}{l}268(130) \\
1569(614) \\
82(17) \\
2 \cdot 6(0 \cdot 9) \\
31(14) \\
85(18)\end{array}$ & $\begin{array}{l}\text { NS } \\
<0.01 \\
<0.01 \\
<0.05 \\
<0.05 \\
\text { NS }\end{array}$ & $\begin{array}{l}689(94) \\
1719(766) \\
113(24) \\
3 \cdot 5(1 \cdot 7) \\
29(15) \\
122(20)\end{array}$ & $\begin{array}{l}678(94) \\
1275(487) \\
104(21) \\
4 \cdot 4(2 \cdot 4) \\
39(16) \\
114(17)\end{array}$ & $\begin{array}{l}\text { NS } \\
<0.05 \\
<0.01 \\
<0.05 \\
<0.05 \\
\text { NS }\end{array}$ \\
\hline$(\mathrm{mm} \mathrm{Hg})$ & $28(11)$ & $21(9)$ & $<0.05$ & $39(10)$ & $36(10)$ & NS \\
\hline
\end{tabular}

$\star$ Significant differences between values obtained during the control period and those obtained after captopril administration.

obtained during the minute before exercise termination. A plateau of $\mathrm{VO}_{2}$ and a disproportionate rise in $\dot{\mathrm{V}} \mathrm{CO}_{2}$ signalled the onset of anaerobic metabolism and maximal exercise capacity.

Patients were allowed to rest for at least four hours. After baseline conditions were re-established and homeostasis again assured, captopril $25 \mathrm{mg}$ was given orally. Resting haemodynamic measurements were repeated 30 and 45 minutes later. Incremental supine bicycle exercise was then repeated to maximal tolerance as described above, with haemodynamic measurements, blood collection, and respiratory gas analysis being obtained during the last minute of each stage. Each patient again exercised to fatigue as verified by a plateau in $\mathrm{V}_{2}$ and a disproportionate increase in $\mathrm{VCO}_{2}$.

\section{STATISTICAL ANALYSIS}

Values are expressed as mean (SD). Data at rest and during exercise and before and after captopril were analysed by the paired $t$ test or the Wilcoxon rank sum test. Measurements obtained at rest and during max-
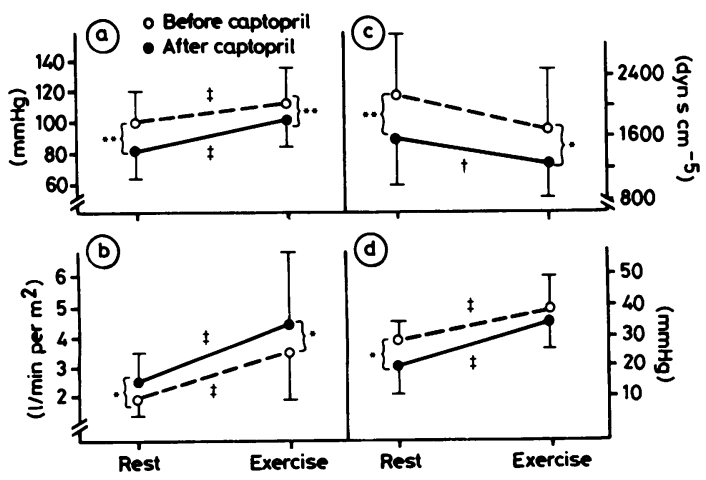

Fig. 1 Effect of captopril on (a) blood pressure, (b) cardiac index, (c) systemic vascular resistance, and (d) pulmonary capillary wedge pressure at rest and during exercise. Values are mean $(S D) .{ }^{\star} p<0.05$ precaptopril vs postcaptopril; $\star \star ~ p<0.01$ precaptopril vs postcaptopril; $\dagger p<0.05$ rest vs exercise; $\ddagger p<0.01$ rest vs exercise. imal exercise before treatment were compared with those obtained at rest and during the comparable exercise stage after treatment. Statistical significance is defined as $\mathrm{p}<0.05$.

\section{Results}

\section{RESTING HAEMODYNAMIC RESPONSE TO CAPTOPRIL (TABLE, FIG. 1)}

There was no significant difference in any of the resting haemodynamic variables obtained before exercise on the morning of the investigation and before administration of captopril several hours after the completion of exercise. Thus a resting baseline was re-established before captopril administration. Captopril decreased the mean blood pressure by $16.7 \%$ $(\mathrm{p}<0.01)$ and the systemic vascular resistance by $26.6 \%(\mathrm{p}<0.01)$, while the cardiac index increased by $19.7 \%(p<0.05)$. Since there was no significant change in heart rate, the increment in cardiac index was secondary to a $16.7 \%$ increase in stroke volume index $(p<0.05)$. Captopril reduced the pulmonary capillary wedge pressure by $24.6 \%(p<0.05)$.

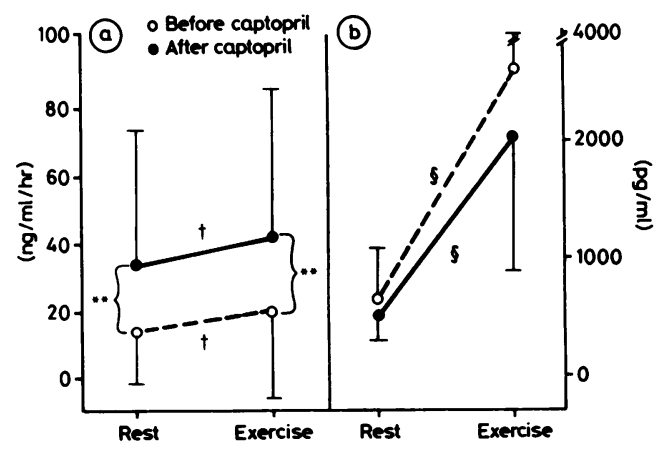

Fig. 2 Effect of captopril on (a) plasma renin activity and (b) plasma noradrenaline concentration at rest and during exercise. Values are mean $(S D) .{ }^{\star \star} p<0.01$ precaptopril vs postcaptopril; $+p<0.01$ rest vs exercise; $\$ p<0.001$ rest vs exercise.

Conversion: traditional to $S I$ units-renin: $1 \mathrm{ng} / \mathrm{ml} \approx 0.77$ mmol/l; noradrenaline $1 \mathrm{pg} / \mathrm{ml} \approx 0.059 \mathrm{nmol} / \mathrm{l}$. 
EFFECT OF CAPTOPRIL ON EXERCISE

HAEMODYNAMICS (TABLE, FIG. 1)

During maximal exercise, captopril reduced the mean blood pressure by $8.2 \%(\mathrm{p}<0.01)$ and systemic vascular resistance by $25.6 \%(\mathrm{p}<0.05)$. The cardiac index increased by $24.4 \%(\mathrm{p}<0.05)$ and the stroke volume index by $32.9 \%(\mathrm{p}<0.05)$. The heart rate during exercise did not differ after captopril compared with pretreatment values. Captopril did not decrease the pulmonary capillary wedge pressure during exercise. There were no significant changes in exercise duration from a pretreatment time of $5 \cdot 1(1 \cdot 9)$ minutes or in maximal oxygen consumption from a pretreatment value of $689(94) \mathrm{ml} / \mathrm{min}$ after captopril. The respiratory quotient, or ratio of $\dot{\mathrm{V}} \mathrm{CO}_{2}$ to $\dot{\mathrm{V} O}{ }_{2}$, was $1 \cdot 0(0 \cdot 1)$ at maximal exercise before treatment and $1 \cdot 1(0 \cdot 1)$ after captopril (NS).

\section{PLASMA RENIN ACTIVITY AND NORADRENALINE} CONCENTRATION (FIG. 2)

The resting plasma renin activity was $13.4(16.0) \mathrm{ng} /$ $\mathrm{ml} / \mathrm{hr}(10 \cdot 3(12 \cdot 3) \mathrm{mmol} / \mathrm{l} / \mathrm{hr})$. During exercise, before captopril, the plasma renin activity increased to $20.0(27.8) \mathrm{ng} / \mathrm{ml} / \mathrm{hr}(15.4(21.4) \mathrm{mmol} / \mathrm{l} / \mathrm{hr})(\mathrm{p}<0.01)$. After captopril, the resting plasma renin activity increased further to $32 \cdot 8(39.9) \mathrm{ng} / \mathrm{ml} / \mathrm{hr}(25.2(30.7)$ $\mathrm{mmol} / \mathrm{l} / \mathrm{hr})(\mathrm{p}<0.01)$ and during exercise the value was $44.5(46.1) \quad \mathrm{ng} / \mathrm{ml} / \mathrm{hr}(34.2(35.5) \quad \mathrm{mmol} / \mathrm{l} / \mathrm{hr})$ ( $\mathrm{p}<0.01$ vs control).

The pretreatment resting plasma noradrenaline concentration was $659(433) \mathrm{pg} / \mathrm{ml}(39(26) \mathrm{nmol} / \mathrm{l})$. During supine bicycle exercise, before captopril, values increased to $2622(1486) \mathrm{pg} / \mathrm{ml}(155(88) \mathrm{nmol} / \mathrm{l})$ $(\mathrm{p}<0.001)$. After captopril, neither the resting nor exercise noradrenaline concentration changed significantly.

\section{Discussion}

The improvement in resting cardiac function seen after the administration of captopril in this study is similar to that previously reported.$^{4-8}$ Cardiac output and stroke volume increased as a consequence of the systemic vasodilatory effects of angiotensin converting enzyme inhibition. The fall in pulmonary capillary wedge pressure may be secondary to venodilatation or improved ventricular compliance. Mild and transient increases in limb venous volume have been found with captopril in patients with congestive heart failure and may account, in part, for the reduction in left ventricular filling pressure. ${ }^{6}$

Indices of cardiac function improved during exercise after captopril administration. Cardiac output was greater and systemic vascular resistance lower than pretreatment values. Since captopril did not alter the heart rate the increase in cardiac output during exercise is attributed solely to an increase in stroke volume. Captopril has no known positive inotropic properties and therefore the increase in stroke volume must be a consequence of systemic vasodilatation.

In this study resting plasma renin activity and plasma noradrenaline concentration were higher than values usually obtained in normal subjects in our laboratory. ${ }^{21}$ Both plasma renin activity and plasma noradrenaline concentration increased during exercise before captopril. The increase in plasma noradrenaline concentration during exercise in patients with heart failure has been reported by others. ${ }^{16} 17$ To our knowledge, an increase in plasma renin activity during exercise has not been previously reported in patients with heart failure. It is, however, known to occur in normal subjects. ${ }^{14}$ is Plasma renin activity increased after captopril at rest and during exercise. This increase reflects a loss of negative feedback inhibition consistent with a decrease in angiotensin II concentrations. The vasoactive effects of captopril, however, may also be mediated via the kallikreinkinin and prostaglandin systems; therefore, modulating effects of these hormonal systems cannot be excluded. 2223 After captopril, plasma noradrenaline concentration did not fall either at rest or during exercise. Thus a decrease in sympathetic nervous system activity cannot explain the observed vasodilatation.

During exercise, when autoregulatory phenomenon as well as activation of the renin-angiotensin system and sympathetic nervous system occur, it is not known whether the increased blood flow associated with captopril administration is distributed to exercising muscle or non-exercising tissue. Exogenous administration of angiotensin II produces varying degrees of vasoconstriction depending on the specific regional circulation. ${ }^{24} 25$ Pharmacological doses of angiotensin II result in pronounced vasoconstriction in the limbs of normal subjects. ${ }^{26} 27$ In experimental studies using sodium depleted dogs, converting enzyme inhibition significantly improves adrenal, cerebral, coronary, and renal blood flow but causes only a modest increase in skin blood flow and no improvement in muscle blood flow. ${ }^{28}$ In patients with heart failure studied at rest, captopril does not have a uniform effect on each regional circulation. ${ }^{62930}$ The increase in renal blood flow is disproportionate to the negligible changes that occur in limb, splanchnic, and coronary blood flow.

Since the renin-angiotensin system is stimulated during effort in patients with heart failure, it is possible that the higher concentrations of angiotensin II will have a greater influence on limb vascular resistance during exercise than at rest. Kugler and colleagues, however, have suggested that blood flow to exercising muscle was not increased by angiotensin 
blockade since femoral vein oxygen content measured during bicycle exercise did not change after captopril." In that study, however, limb blood flow was not actually measured.

If blood flow to exercising muscle is influenced by the renin-angiotensin system exercise capacity after the administration of captopril might be expected to improve. Other investigators have assessed the exercise response to captopril and have not found an improvement in exercise capacity after short term administration. ${ }^{12}$ An acute increase in exercise capacity and maximal oxygen consumption has been reported in patients with heart failure after enalapril treatment. ${ }^{31}$ Studies of limb blood flow during exercise are required during angiotensin II inhibition for further elucidation.

\section{References}

1 Gavras H, Flessas A, Ryan TJ, Brunner HR, Faxon DP, Gavras I. Angiotensin II inhibition: treatment of congestive cardiac failure in high-renin hypertension. JAMA 1977; 238: 880-2.

2 Faxon DP, Creager MA, Halperin JL, Gavras H, Coffman JD, Ryan TJ. Central and peripheral hemodynamic effects of angiotensin inhibition in patients with refractory congestive heart failure. Circulation 1980; 61: 925-30.

3 Curtiss C, Cohn JN, Vrobel T, Franciosa JA. Role of the reninangiotensin system in the systemic vasoconstriction of chronic congestive heart failure. Circulation 1978; 58: 763-70.

4 Davis R, Ribner HS, Keung E, Sonnenblick EH, LeJemtel TH. Treatment of chronic congestive heart failure with captopril, an oral inhibitor of angiotensin-converting enzyme. $N$ Engl $\mathcal{F}$ Med 1979; 301: 117-21.

5 Ader R, Chatterjee K, Ports T, Brundage B, Hiramatsu B, Parmley W. Immediate and sustained hemodynamic and clinical improvement in chronic heart failure by an oral angiotensinconverting enzyme inhibitor. Circulation 1980; 61: 931-7.

6 Faxon DP, Halperin JL, Creager MA, Gavras H, Schick EC, Ryan TJ. Angiotensin inhibition in severe heart failure: acute central and limb hemodynamic effects of captopril with observations on sustained oral therapy. Am Hean f 1981; 101: 548-56.

7 Levine TB, Franciosa JA, Cohn JN. Acute and long-term response to an oral converting enzyme inhibitor, captopril, in congestive heart failure. Circulation 1980; 62: 35-41.

8 Dzau VJ, Colucci WS, Williams GH, Curfman G, Meggs L, Hollenberg NK. Sustained effectiveness of converting-enzyme inhibition in patients with severe congestive heart failure. $N$ Engl f Med 1980; 302: 1373-9.

9 Cody RJ, Covit AB, Schaer GL, Laragh JH. Evaluation of a long-acting converting enzyme inhibition (enalapril) for the treatment of chronic congestive heart failure. $\mathrm{f}$ Am Coll Cardiol 1983; 1: 1154-9.

10 DiCarlo L, Chatteriee ${ }^{\tau}$., Parmley WW, et al. Enalapril: a new angiotensin converting enzyme inlibitor in chronic heart failure: acute and chronic hemodynamic evaluations. 7 Am Coll Cardiol 1983; 2: 865-71.

11 Kugler J, Maskin C, Frishman WH, Sonnenblick EH, LeJemtel TH. Regional and systemic metabolic effects of angiotensinconverting enzyme inhibition in patients with severe heart failure.
Circulation 1982; 66: 1256-61.

12 Kramer BL, Massie BM, Topic N. Controlled trial of captopril in chronic heart failure: a rest and exercise hemodynamic study. Circulation 1983; 67: 807-16.

13 Captopril Multicenter Research Group. A placebo-controlled trial of captopril in refractory chronic congestive heart failure. $7 \mathrm{Am}$ Coll Cardiol 1983; 2: 755-63.

14 Kotchen TA, Hartley LH, Rice TW, Mougey EH, Jones LG, Mason JW. Renin, norepinephrine, and epinephrine responses to graded exercise. $\mathcal{F}$ Appl Physiol 1971; 31: 178-84.

15 Fagard R, Amery A, Reybrouck $T$, et al. Effects of angiotensin antagonism on hemodynamics, renin, and catecholamines during exercise. 7 Appl Physiol 1977; 43: 440-4.

16 Francis GS, Goldsmith SR, Ziesche SM, Cohn JN. Response of plasma norepinephrine and epinephrine to dynamic exercise in patients with congestive heart failure. Am $\mathcal{f}$ Cardiol 1982; 49; $1152-6$.

17 Chidsey CA, Harrison DC, Braunwald E. Augmentation of the plasma norepinephrine response to exercise in patients with congestive heart failure. $N$ Engl 7 Med 1962; 267: 650-4.

18 Yang SS, Bentiuoglio LG, Maranhao V, Goldberg H. From cardiac catheterization data to hemodymamic parameters. 2nd ed. Philadelphia: FA Davis, 1978.

19 Sealey JE, Gerten-Banes J, Laragh JH. The renin system: variations in man measured by radioimmunoassay or bioassay. Kidney Int 1972; 1: 240-53.

20 Ben-Jonathan N, Porter JC. A sensitive radioenzymatic assay for dopamine, norepinephrine, and epinephrine in plasma and tissue. Endocrinology 1976; 98: 1497-507.

21 Creager MA, Faxon DP, Rockwell SM, Melby JC, Gavras H, Coffman JD. The effect of the renin-angiotensin system on limb circulation in normal subjects. Am f Physiol 1984; 15: H239-44.

22 Engel SL, Schaeffer TR, Gold BI, Rubin B. Inhibition of pressor effects of angiotensin I and augmentation of depressor effects of bradykinin by synthetic peptides. Proc Soc Exp Biol Med 1972; 1: $240-4$.

23 Swartz SL, Williams GH, Hollenberg NK, Levine L, Dluhy RG, Moore TJ. Captopril-induced changes in prostaglandin production: relationship to vascular responses in normal man. $f$ Clin Invest 1980; 65: 1257-64.

24 Heyndrickx GR, Boettcher DH, Vatner ST. Effects of angiotensin, vasopressin, and methoxamine on cardiac function and blood flow distribution in conscious dogs. Am $\mathcal{F}$ Physiol 1976; 231: $1579-87$.

25 Mark AL, Abboud FM, Schmid PG, Heistad DD, Mayer HE. Differences in direct effects of adrenergic stimuli on coronary, cutaneous and muscular vessels. $f$ Clin Invest 1972; 51: 279-87.

26 Scroop GC, Walsh JA, Whelan RF. A comparison of the effects of intra-arterial and intravenous infusions of angiotensin and noradrenaline on the circulation in man. Clin Sci 1965; 29: 315-26.

27 Wood JE. Peripheral venous and arteriolar responses to infusions of angiotensin in normal and hypertensive subjects. Circ Res 1961; 9: 768-72.

28 Gavras H, Liang C-S, Brunner HR. Redistribution of regional blood flow after inhibition of the angiotensin converting enzyme. Circ Res 1978; 43 (suppl 1): 59-63.

29 Creager MA, Halperin JL, Bernard DB, et al. Acute regional circulatory and renal hemodynamic effects of converting-enzyme inhibition in patients with congestive heart failure. Circulation 1981; 64: 483-9.

30 Halperin JL, Faxon DP, Creager MA, et al. Coronary hemodynamic effects of angiotensin inhibition by captopril and teprotide in patients with congestive heart failure. Am $\mathcal{F}$ Cardiol 1982; 50: $967-72$.

31 Friedman SD, Creager MA, Faxon DP, et al. Cardiovascular response to exercise in heart failure patients given enalapril (Abstract]. Circulation 1983; 68 (suppl 3): 130. 